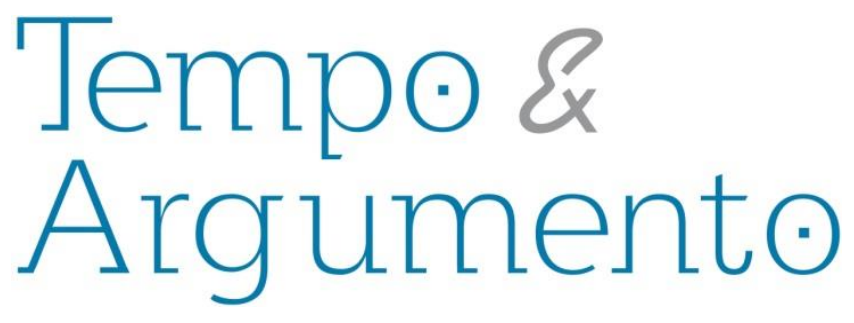

\title{
Acordes D`Além-Mar - Memórias das Bandas Filarmônicas Portuguesas nas Américas no Século XX
}

\section{Resumo}

As bandas filarmônicas são das manifestações culturais mais significativas na vida social portuguesa, sobretudo, nas regiões centro e norte do país (Granjo, 2005). Observa-se que, no contexto do associativismo migrante, o elo de memória com a tradição e os costumes portugueses é estabelecido nas celebrações e instituições criadas pelos migrantes que constituem lugares de memória (Nora, 1993) nos quais as representações simbólicas e ritualizações portuguesas são materializadas, dentre elas, as bandas filarmônicas, objeto deste estudo de doutoramento com foco na cidade do Rio de Janeiro. Investigamos a atividade filarmônica de migrantes portugueses inicialmente naquela cidade e, em numa perspectiva sincrônica, o fizemos em escala planetária nos séculos XX e XXI. Desenvolvemos extensa revisão de literatura sobre migração portuguesa, pesquisa em periódicos locais e na Internet e contatamos músicos e dirigentes associativos no Rio de Janeiro, Estados Unidos, Canadá e Venezuela. Neste artigo, discutimos a distribuição das bandas filarmônicas portuguesas em atividade na diáspora da migração portuguesa nas Américas articulando-a aos fluxos migratórios que lhes deram origem. Na cidade do Rio de Janeiro, por exemplo, existem atualmente duas bandas filarmônicas portuguesasem atividade - a Banda Portugal e a Banda Irmãos Pepino, fundadas, respectivamente, em 1921 e 1958. Todavia, a pesquisa realizada nos periódicos locais revelou que diversos grupos congêneres foram criados e encerraram suas atividades nesta cidade como a Banda do Centro Musical da Colônia Portuguesa (1920-1930), a Banda Lusitana (19231998) e a Banda União Portuguesa (1924-1929).

\author{
Antonio Henrique Seixas de Oliveira' \\ Doutorando do Programa de \\ Pós-Graduação em Memória Social na \\ Universidade Federal do Estado do Rio de \\ Janeiro (UNIRIO). \\ Rio de Janeiro - Brasil \\ ahseixas@uol.com.br \\ Diana de Souza Pinto \\ Professora do Programa de \\ Pós-Graduação em Memória Social na \\ Universidade Federal do Estado do Rio de \\ Janeiro (UNIRIO). \\ Rio de Janeiro - Brasil \\ dianap@globo.com
}

Palavras-chave: Bandas Filarmônicas. Portugal. Migração.

Américas. Memória.

\section{Para citar este artigo:}

OLIVEIRA, Antonio Henrique Seixas de; PINTO, Diana de Souza. Acordes D`Além-Mar - Memórias das Bandas Filarmônicas Portuguesas nas Américas no Século XX. Tempo e Argumento, Florianópolis, v. 9, n. 22, p. 08 - 43, set./dez. 2017.

\section{DOI: $10.5965 / 2175180309222017008$ \\ http://dx.doi.org/10.5965/2175180309222017008}

\footnotetext{
${ }^{1}$ Bolsista da CAPES/Programa de Doutorado Sanduíche no Exterior/Processo n 88881.132465/2016-01.
} 


\title{
Chords from Portugal - Memories of Portuguese Philharmonic Bands of the Twentieth Century in the Americas
}

\begin{abstract}
Philharmonic bands, especially those from the middle and north of Portugal, represent one of the most significant cultural expressions in the country's social life (Granjo, 2005). Within the context of migrants' associativism, the memory link is established with Portuguese traditions and customs in the celebrations and institutions created by such migrants. These institutions are places of memory (Nora, 1993), where Portuguese symbolic representations and rituals are materialized. This doctoral study investigates the philharmonic activities carried out by Portuguese migrants, particularly from the city of Rio de Janeiro at first and, in a synchronic perspective, in a planetary scale at the $20^{\text {th }}$ and $21^{\text {st }}$ centuries. Literature review about Portuguese migration, local newspapers and the Internet have been thoroughly examined; musicians and associations' leaders from Rio de Janeiro, the United States, Canada and Venezuela have been contacted, also. This article discusses the distribution of currently acting Portuguese philharmonic bands within the diaspora of Portuguese migration in the Americas in association with the migratory flows that have originated them. Two Portuguese philharmonic bands, for example, are acting in the city of Rio de Janeiro nowadays - Banda Portugal and Banda Irmãos Pepino (Pepino Brothers Band), established in 1921 and 1958 respectively. Research done on local newspapers, however, reveals that many similar groups were assembled in Rio, but later came to an end, as the Banda do Centro Musical da Colônia Portuguesa (1920-1930), Banda Lusitana (1923-1998) and Banda União Portuguesa (1924-1929).
\end{abstract}

Keywords: Philharmonic Bands; Portugal; Migration; Americas; Memory. 


\section{Introdução}

Os portugueses têm sido uma população móvel por todo o mundo, desde o século XVI, segundo Eric Hobsbawm (Hobsbawm, 2016). Como iremos documentar, nos diferentes locais onde se fixaram, levaram consigo as suas práticas musicais chegando a instituir agrupamentos no âmbito do associativismo migrante. O atlas Portugal - Atlas das Migrações Internacionais (Pires, 2010), nos informa sobre os diversos países de destino da migração portuguesa e, a nossa pesquisa revelou que, em diversos destes destinos, foram criados, por portugueses, agrupamentos musicais à semelhança das bandas filarmônicas em Portugal.

Neste artigo, apresentamos um histórico resumido da criação destes agrupamentos em terras lusitanas observando seus contextos performativos, atuações e relevância na cultura popular portuguesa, sobretudo nas regiões centro e norte de Portugal onde têm maior atuação e de onde partiu a grande maioria dos migrantes para as Américas, assim como as Regiões Autônomas dos Açores e da Madeira.

Em seguida, discorreremos sobre as relações entre migrações, música e memória, discutindo a força da música como elemento de coesão no contexto migrante, além de questões como o associativismo nos países da diáspora portuguesa. Apresentaremos, ainda, um mapeamento das bandas filarmônicas portuguesas nas Américas - Brasil, EUA, Canadá e Venezuela, sustentada na investigação bibliográfica e pesquisa na internet. No tocante às bandas filarmônicas portuguesas da cidade do Rio de Janeiro, a pesquisa fundamentou-se em revisão bibliográfica e pesquisa em periódicos publicados entre 1920 e os dias atuais, prosseguindo, posteriormente, com a realização de entrevistas com músicos e maestros das bandas filarmônicas portuguesas ainda em atividade nesta cidade.

\section{Bandas filarmônicas em Portugal}

Bandas filarmônicas ou somente filarmônicas são os nomes dados, em Portugal, às bandas de música civis amadoras. Consideraremos, para efeito de definição, a banda de música como um agrupamento musical formado por instrumentos de sopros, tais como: 
Pedro Sousa (2006) atribui o surgimento das bandas civis em Portugal ao desenvolvimento das bandas militares e da sua forte presença na sociedade civil. De acordo com Pedro Freitas (1946), as bandas civis nasceram após 1822, em Portugal, com o aparecimento da novidade da Filarmônica, instituída pelos ideais do Liberalismo e através de João Domingos Bomtempo, que trouxe da Inglaterra o modelo de Sociedade Filarmônica e, segundo o autor, fundou em Lisboa, em 1822, a primeira Sociedade Filarmônica em Portugal. Ainda segundo Freitas (1946), a partir de 1834 teve início a popularidade das bandas filarmônicas por todo o país, no ambiente liberal, com a criação dos Batalhões de Voluntários para a defesa da liberdade política constitucional, num período em que as bandas contribuíram para divulgar a música na vida pública através das Sociedades de Recreio Popular e, em alguns casos, com a integração das bandas filarmônicas nos partidos políticos.

A popularização das filarmônicas também decorreu da necessidade de execução musical nas procissões e festas religiosas dos padroeiros das vilas e aldeias, segundo Freitas (1946) e André Granjo (2005). A este propósito Freitas (1946) afirma que:

Os serviços religiosos muito da música careciam. As procissões tinham que a possuir. E como no princípio do Século XIX ainda as bandas populares não davam sintomas de sua aparição, aqui temos, por exemplo, a charamela do arcebispo de Braga, "corporação de oito músicos, tocadores de instrumentos de vento, que tinha por obrigação tocar nas festas da cidade e da catedral, e acompanhar as procissões". (FREITAS, 1946, p. 39)

Tristão Nogueira (2010) atesta que, em Portugal "A cultura religiosa foi a grande financiadora e impulsionadora das Bandas Filarmónicas. As Bandas cantavam ou tocavam em missas, procissões e arraiais, apresentando composições de cariz popular" (NOGUEIRA, 2010, p. 29). Complementarmente à análise de Freitas (1946) e Nogueira (2010), Granjo (2005) considera que, no século XIX, as bandas filarmônicas tinham por função principal acompanhar os rituais nas festas dos santos padroeiros, e estas festas, 
Acordes D`Além-Mar - Memórias das Bandas Filarmônicas Portuguesas nas Américas no Século XX

Figura 1 - Sociedade Filarmônica Bejense (1873)

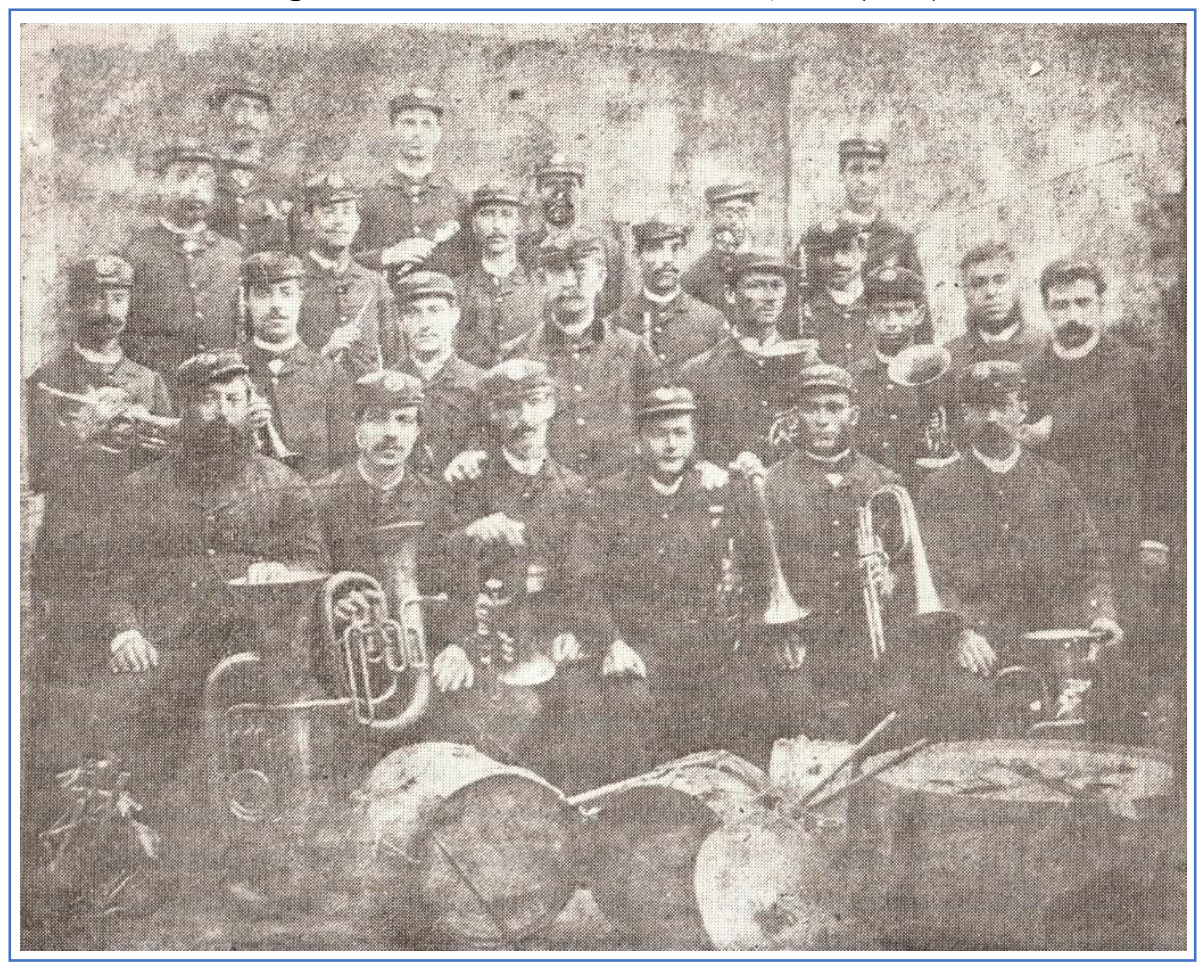

Fonte: Freitas (1946) - p. 166

Figura 2 - Sociedade Filarmónica Barreirense (1895)

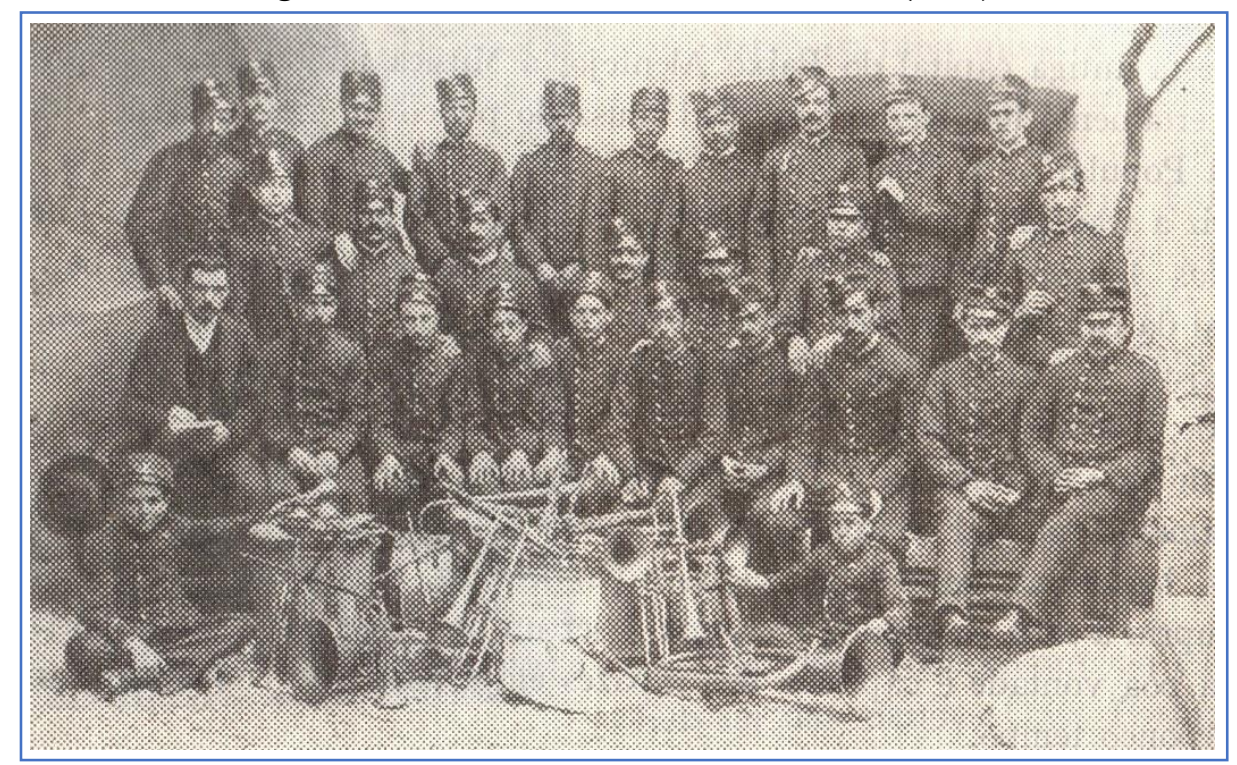

Fonte: Freitas (1946) - p. 338 
Podemos observar, nas figuras 1 e 2, a influência das bandas militares sobre as filarmônicas, sobretudo, com relação aos uniformes das bandas civis prática que, em muitos casos, é utilizada ainda nos dias de hoje.

O modelo organizacional das bandas filarmônicas em Portugal é basicamente o mesmo em todo o país - associações culturais e recreativas, sem fins lucrativos, constituídas de sócios que pagam anuidades e que compõem uma Assembleia Geral e uma Diretoria Administrativa, responsável pela gerência de suas atividades em conjunto com um maestro, segundo Granjo (2005). Em geral, o maestro é pago para reger a banda e lecionar ou coordenar a sua escola de música. A Diretoria Administrativa organiza os concertos, assina os contratos em nome da instituição e cuida da parte financeira da sociedade, do marketing e demais funções administrativas.

O governo português reconhece a existência de cerca de 800 bandas filarmônicas em todo país, segundo Katherine Brucher (2005), e a autora observa que, desde o fim do século XIX até os dias atuais, quase toda aldeia, vila ou cidade celebra o dia dos seus santos padroeiros com festas, nas quais, tomam parte as bandas filarmônicas. Os organizadores destas festas as contratam para tocar, nessas ocasiões, em diversas atividades como desfiles de rua, missas, procissões e concertos. Nestas festas que, na maioria dos casos, decorrem durante um dia inteiro, as bandas se apresentam em diferentes momentos como na arruada ou entrada (desfile matinal para saudar o local da festa, seus organizadores - também conhecidos como mordomos - e os principais patrocinadores), na missa, na procissão e nos concertos que podem decorrer várias vezes ao dia e que, à noite, são seguidos pela despedida que encerra as atividades da banda na festa, naquele dia. É comum, nessas festas, a participação de, pelo menos, duas bandas, o que evoca um tema muito presente na relação entre as bandas filarmônicas em Portugal - a rivalidade.

Podemos constatar a relevância deste tema para as bandas filarmônicas em Portugal, pois Brucher (2005) dedica um capítulo inteiro de sua tese a ele. A autora 
considera que, no centro e no norte de Portugal, as bandas filarmônicas constroem suas reputações em apresentações chamadas despiques nas quais, durante os concertos, duas bandas se revezam apresentando números musicais como parte do entretenimento secular.

Embora não exista um regulamento para os despiques, estes possuem algumas convenções que são seguidas por todas as bandas filarmônicas e que foram possíveis de constatar na observação participante realizada no ano de 2017 por Antonio Oliveira, um dos autores deste artigo. A banda que inicia o despique é a chamada "banda da festa" que executa o primeiro número musical, seguido pela apresentação de um número musical pela "banda convidada" e que deverá, obrigatoriamente, pertencer ao mesmo gênero musical executado pela anterior. Assim, durante todo o concerto, as bandas se alternam numa dinâmica de pergunta e resposta e, para tal, é imprescindível que possuam um amplo repertório para que estejam aptas a responder à altura o gênero musical executado pela banda anterior.

Brucher (2005) atesta que, embora um despique não seja oficialmente, uma competição, não tem valor se não for competitivo e, nos despiques, os músicos se referem a tocar "contra" a outra banda, salientando o caráter competitivo. Os membros das bandas filarmônicas consideram um "despique ideal" quando este inflama tanto o entusiasmo dos músicos como do público, enquanto as bandas travam um "duelo sonoro". Durante o verão, as bandas filarmônicas se apresentam em despiques quase todos os fins de semana e estes têm implicações sociais e econômicas reais para ambas as bandas e para as comunidades que as recebem para o evento, pois, quando são bemsucedidos, ajudam as bandas a estabelecer e manter suas reputações quanto ao nível artístico. Cabe destacar que os organizadores das festas (mordomos) preferem contratar as bandas que são conhecidas por realizarem grandes apresentações, pois essas bandas têm o potencial de atrair mais público para as festas.

As filarmônicas, embora se considerem grupos amadores, cobram para tocar nas festas, as quais chamam de serviços e, do valor recebido, uma parte é retirada para a instituição mantenedora da banda e o restante é dividido entre os músicos. 
É relevante assinalar que cada banda possui a sua bandeira que é carregada à frente do grupo e ladeada por membros da sua diretoria quando desfilam em arruadas ou procissões. A bandeira pode conter diversos símbolos ligados à terra de origem da banda, como o brasão da localidade de sede, o brasão da banda, o nome da banda e da localidade à qual ela pertence e o ano de sua fundação. Também em nossa observação participante foi possível constatar que as filarmônicas têm utilizado grandes banners, que são afixados por detrás da banda nas apresentações com informações como nome, website, endereço, telefone para contatos e logomarcas de apoiadores ou patrocinadores.

O repertório das bandas filarmônicas inclui marchas de rua, marchas de procissão, marchas de concerto, missas cantadas e tocadas, arranjos de canções populares e danças folclóricas, rapsódias, transcrições orquestrais e obras originais para grupos de sopros em geral. Cada momento da festa em que as filarmônicas participam requer um tipo de música apropriado, e as bandas possuem, normalmente, um amplo repertório para atender a cada um deles. Brucher (2005) destaca, ainda, que o repertório é, também, um diferencial para a contratação das bandas para essas festas. A banda que se destaca por tocar algo diferente ou que nenhuma outra banda executa recebe mais contratos para as festas, como atesta a autora ao se referir a Fausto, maestro da Banda Filarmônica dos Covões, situada na região da Bairrada, no Distrito de Coimbra, divisa com Aveiro, norte de Portugal:

Fausto frequentemente faz o arranjo do salmo durante o intervalo entre a arruada da manhã e a missa da tarde. Ele afirma que outros maestros de bandas não fazem arranjos dos salmos e que os padres preferem a Banda dos Covões pois ele está disposto a adaptar a música para a missa conforme as suas necessidades. (BRUCHER, 2005, p. 57, tradução nossa)

Apresentamos, abaixo, um mapa com a distribuição das Bandas Filarmônicas por Distrito, em Portugal, e também nos Arquipélagos dos Açores e da Madeira. 
Figura 3 - Mapa de Portugal por Distritos e número de bandas filarmônicas por Distrito e Regiões Autônomas

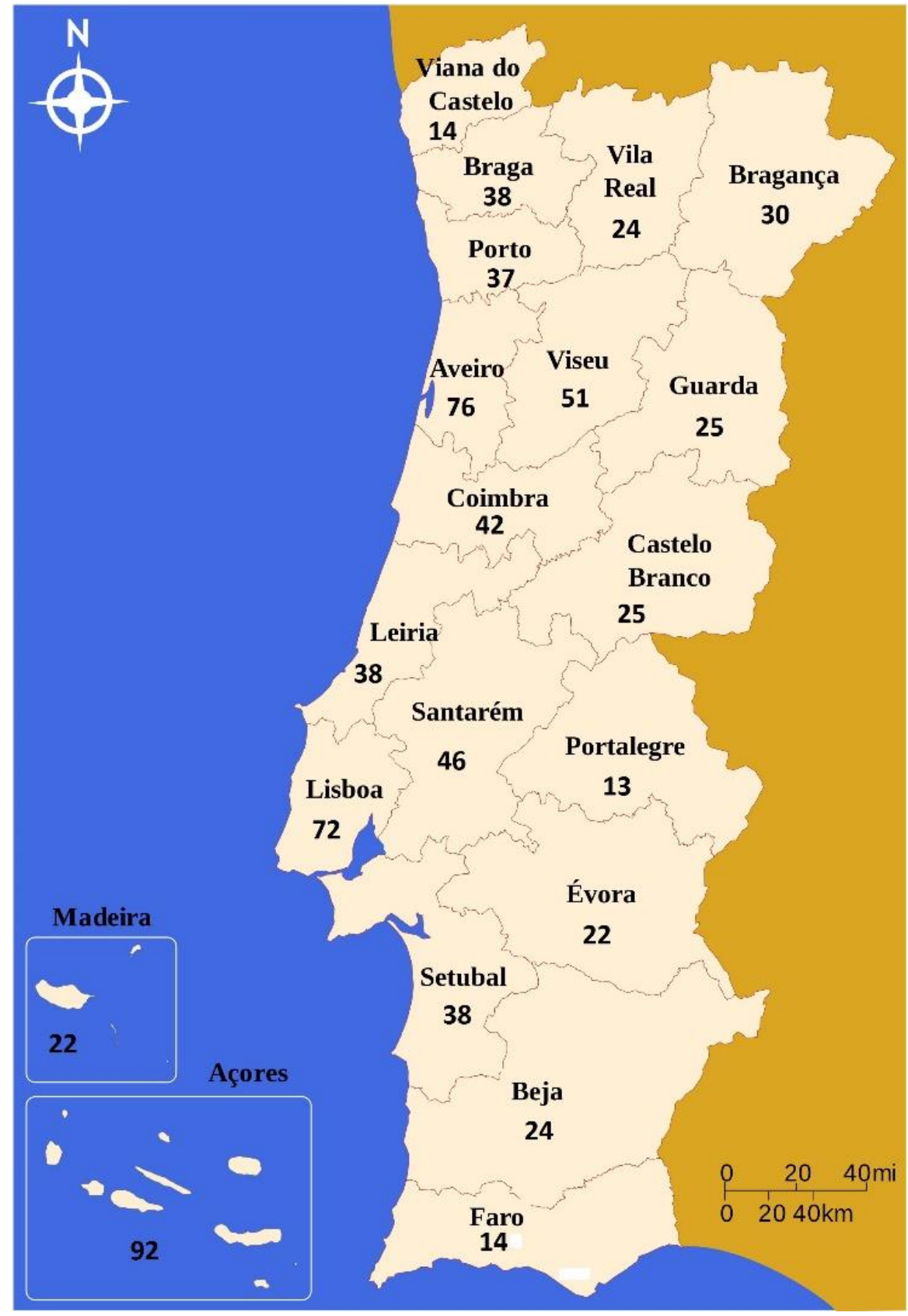

Fonte: www.bandasfilarmonicas.com. Acesso em 07/08/2017.

Uma leitura preliminar do mapa acima nos permite inferir que se tomarmos a porção centro-norte de Portugal, que inclui os Distritos de Leiria, Castelo Branco, Coimbra, Guarda, Viseu, Aveiro, Porto, Braga, Vila Real, Bragança e Viana do Castelo, observaremos que o número de bandas filarmônicas nestas localidades chega a 400, e na região centro-sul que inclui os Distritos de Lisboa, Portalegre, Évora, Setúbal, Beja e Faro 
o número de bandas filarmônicas é de 229. Há uma maior concentração de bandas na porção centro-norte do país, se nos referirmos ao continente, mas também cabe destacar os números nas regiões autônomas dos Açores e da Madeira que somam, juntas, 114 bandas filarmônicas, um número bastante significativo se considerarmos suas pequenas extensões territoriais, demografias e a distância com relação ao continente Europeu.

O trabalho etnográfico de Brucher (2005) junto à Banda Filarmónica dos Covões, na região da Bairrada, Distrito de Coimbra, em Portugal, identificou práticas que são comuns às demais bandas filarmônicas no país e que, com pequenas variações, determinam os modelos de atuação destes grupos, sobretudo nas festas de santos padroeiros nas regiões centro e norte do país. A autora analisa, em sua pesquisa, o papel da Banda Filarmônica dos Covões ao se apresentar na festa de Santo Antônio, santo padroeiro da Freguesia dos Covões e afirma que:

O santo padroeiro Santo António é um símbolo da comunidade, e a festa em sua honra é um ponto crucial na construção da identidade local enraizada na terra dos Covões. A festa afirma a comunidade, o seu território, as pessoas que ali vivem, sua história comum, e o estado atual da comunidade. Ao participar nesta festa, a Banda Filarmônica dos Covões marca os seus papeis musicais e sociais na sua terra natal. A banda também é um símbolo da terra.Segundo a tradição, a banda tem participado na festa de Santo Antônio desde a suafundação, em 1868, e a banda também é conhecida pelo nome da sua terra - "a Banda dos Covões." (BRUCHER, 2005, p. 33 - tradução nossa)

A citação acima nos permite constatar que a festa do santo padroeiro e a participação da banda, nessa festa, constroem as identidades locais da sua terra natal. É comum que, em Portugal, as pessoas identifiquem as bandas filarmônicas, na maioria dos casos, não pelo seu nome oficial, mas pelo nome da terra às quais pertencem como, por exemplo: "a Banda dos Covões" (Banda Filarmónica dos Covões), "a Banda de Monção" (Banda Musical de Monção), "a Banda da Mamarrosa" (Banda Filarmónica da Mamorrosa) e "a Banda da Trofa” (Banda de Música da Trofa), auxiliando na construção das suas identidades locais e da sua territorialidade. 
Diante da constatação de que as bandas filarmônicas representam importante elemento da cultura e da identidade portuguesa, em especial nas regiões centro-norte de Portugal e nas Regiões Autônomas da Madeira e dos Açores, é compreensível que, nos países para os quais houve um grande fluxo de migrantes portugueses, as práticas musicais da terra natal fossem transportadas e reproduzidas como construto da memória coletiva e afetiva (Halbwachs, 2003), além de operar, também, como elemento de coesão nos países de acolhimento. Na próxima seção, discutiremos as relações entre música, migração e memória observando de que forma a música opera nas comunidades migrantes como elemento de coesão e de preservação da identidade e das memórias.

\section{Bandas filarmônicas portuguesas nas Américas - música, migração e memória}

[...] os orfeões e bandas trazem aos nossos ouvidos exilados, o ritmo e o colorido da terra distante e ensinam aos nossos filhos e dizem aos nossos amigos como se vive e canta, como se ri e chora das bandas de lá do Atlântico.

(Álbum da Colônia Portuguesa no Brasil, 1929, p. 410)

Em uma das observações participantes de que o autor teve a oportunidade de colaborar, por ocasião de seu estágio doutoral na Universidade de Aveiro², em Portugal, foi possível comparecer a um concerto da Filarmônica Portuguesa de Paris, na cidade de Macedo de Cavaleiros, situada no Distrito de Bragança, região de Trás-os-Montes, no norte de Portugal.

A Filarmônica Portuguesa de Paris se orgulha de ser a única filarmônica portuguesa na Europa, fora de Portugal, conforme palavras do seu próprio presidente que, na abertura do concerto, iniciou seu discurso com a palavra "saudade" afirmando que a saudade da terra natal é o principal motivador para que aquele grupo de músicos, todos migrantes portugueses ou luso-descendentes, existisse. O sentimento de

\footnotetext{
2 Doutorado Sanduíche realizado entre maio e agosto de 2017 na Universidade de Aveiro - Portugal, sob orientação da Profa. Dra. Maria do Rosário Pestana, com apoio da CAPES através do Programa de Doutorado Sanduíche no Exterior.
} 
saudosismo para com a terra natal, observado neste concerto, nos parece comum às bandas filarmônicas existentes nos diferentes países da diáspora portuguesa, conforme podemos observar na citação que abre esta seção. Os poucos jovens músicos da Filarmónica Portuguesa de Paris, fazem parte de uma primeira geração de migrantes que, na banda, aprendem a importância da preservação dos valores portugueses, mantendo aquilo que se herdou.

Em continuação ao seu discurso, o presidente exaltou que todos ali eram músicos amadores que se reúnem, semanalmente nos ensaios, para tocar os gêneros musicais da terra natal. A obra musical que abriu o espetáculo foi a marcha de concerto António Nogueira, do compositor português llídio Costa, que foi seguida por um repertório exclusivamente de compositores portugueses como Valdemar Sequeira e João Neves. Neste sentido, podemos constatar que o elemento diferenciador das bandas amadoras portuguesas para as demais bandas de música de outros países reside no repertório de autores portugueses que, somente estes grupos musicais executam e que consiste dos gêneros musicais já descritos na seção 2 deste artigo.

Em terras estrangeiras, os migrantes portugueses procuraram manter os costumes da terra natal através do associativismo e, a propósito do associativismo em comunidades migrantes, Thomas Turino (2008) afirma que, para existir como uma comunidade de imigrantes, as pessoas associam-se frequentemente com base na identidade do "lar original" e operam em redes comunitárias no país anfitrião de modo que a comunidade permaneça reunida e ofereça estratégias de socialização. Complementarmente a Turino, Ana Nogueira (1998), considera que o associativismo se organiza a partir de vínculos familiares e étnicos, perpetuados nas instituições criadas pelo mutualismo migrante e, citando Sérgio Buarque de Holanda (1997), afirma que a solidariedade entre os migrantes existe, somente, onde há vinculação de sentimentos mais do que relações de interesse - no recinto doméstico ou entre amigos. 0 associativismo poderia ser visto como uma reprodução da família e extensão dos vínculos de amizade a um grupo maior além da reedição do costume do mutirão, de socorreremse uns aos outros no trabalho agrícola, ocasião, também, para animadas festas. As bandas filarmônicas portuguesas compõem um fenômeno ainda mais significativo do 
associativismo, segundo Nogueira (1998), na medida em que mantêm a representação da cultura portuguesa através da música, forte componente na tradição camponesa dos migrantes. Neste sentido, Baily e Collyer (2006) consideram que a música tem o poder de evocar memórias e capturar emoções com as quais todos podemos nos identificar, migrantes ou não.

Cabe ressaltar que as bandas filarmônicas portuguesas nos diferentes países funcionam, também, como redes de inserção social e no mercado de trabalho para os migrantes recém-chegados. Em entrevista realizada no Rio de Janeiro (2017) com o Sr. José Catarino, que atuou como músico e diretor na Banda Portugal e é filho do maestro Heitor Catarino, que dirigiu esta banda entre 1948 e 1991, nos informa em determinado ponto da entrevista que:

Aí o Seu Pinho... ele entrou em (19)40 e ele estudou em Portugal. Aos quinze ele entrou para a banda e com vinte e dois anos veio para o Brasil naquele tempo, músicos... Diretor musical não sei se foi o Felipe Medeiros, iam esperar os navios que chegavam no Cais do Porto para requisitar quem era músico, quem é que queria fazer parte da banda, e eles faziam isso! (Entrevista com José Catarino, 2017)

Em entrevista com o Sr. João Silva, um dos músicos fundadores da Azores Band of Escalon, uma das 14 bandas filarmônicas portuguesas do estado da Califórnia, nos Estados Unidos, este nos revelou que muitos migrantes chegavam dos Açores sem trabalho e, já no primeiro ensaio junto à banda, saíam com emprego conseguido por outros músicos ou diretores da banda.

As bandas filarmônicas, nas comunidades portuguesas da diáspora, estabeleceram verdadeiros lugares de memória nos quais as representações simbólicas e ritualizações da terra natal são materializadas. Para Pierre Nora (1993), os lugares de memória devem possuir três sentidos simultaneamente - material, simbólico e funcional, ainda que em graus diversos. Mesmo um lugar de aparência puramente material, como um depósito de arquivos, só será um lugar de memória se a imaginação o investir de uma aura simbólica. Mesmo um lugar puramente funcional, como um testamento, ou uma associação de migrantes, por exemplo, só se transformam em lugares de memória se forem objeto de 
um ritual. O autor completa suas considerações a propósito dos lugares de memória afirmando que:

Mesmo um minuto de silêncio, que parece o exemplo extremo de uma significação simbólica, é ao mesmo tempo o recorte material de uma unidade temporal e serve, periodicamente, para uma chamada concentrada da lembrança. Os três aspectos coexistem sempre. Trata-se de um lugar de memória tão abstrato quanto a noção de geração? É material por seu conteúdo demográfico; funcional por hipótese, pois garante, ao mesmo tempo, a cristalização da lembrança e sua transmissão; mas simbólica por definição visto que caracteriza por um acontecimento ou uma experiência vividos por um pequeno número uma maioria deles que não participou. (NORA, 1993, p. 21-22)

A criação das associações e bandas filarmônicas portuguesas nos países da diáspora, fruto do desejo de preservação da memória de caráter nacionalista do migrante, integra as dimensões material, simbólica e funcional, configurando-se, assim, em um lugar de memória. Nora (1993) afirma, ainda, que um lugar de memória só pode ser assim considerado se possuir uma vontade de memória, pois, do contrário, seria apenas um lugar de história.

O processo de construção de uma identidade nacional e da memória coletiva nos migrantes portugueses pode ser fundamentado pelas considerações de Nora (1993) referindo-se a Halbwachs, quando este afirma que "a memória emerge de um grupo que ela une, o que quer dizer que há tantas memórias quantos grupos existem; que ela é, por natureza, múltipla e desacelerada, coletiva, plural e individualizada" (NORA, 1993). Neste sentido cabe ressaltar que o grupo tem uma importância capital para a compreensão da Memória Coletiva e Gérard Namer, no posfácio do livro Os Quadros Sociais da Memória, de Halbwachs (1994) define que o que é essencial para a existência de um grupo é a forma de compartilhar a compreensão e avaliação do mundo. "Define-se por sua visão, por seu pensamento que é, a um só modo, razão e memória; uma memória de fatos, de pessoas" (Namer in Halbwachs, 1994, p. 309). Côrte-Real (2010) considera que as práticas musicais nos contextos migrantes, entre elas as bandas filarmônicas, operam como uma manifestação natural do "saudosismo" - a saudade portuguesa simbolicamente carregada, que expressa sentimentos de unidade entre os imigrantes, e que, "como parte 
de uma estratégia romantizada da propaganda nacionalista foi tida como impossível de traduzir exatamente noutras línguas" (CÔRTE-REAL, 2010, p. 78).

Nas próximas subseções, apresentaremos um mapeamento da distribuiç̧ão das bandas filarmônicas portuguesas em atividade na diáspora da migração portuguesa para as Américas e aos fluxos migratórios que lhes deram origem.

\subsection{Bandas filarmônicas portuguesas no Brasil}

O grande fluxo migratório de Portugal para o Brasil que se deu na primeira metade do século XX teve influência de diversos fatores como a abolição da escravatura no Brasil (1888), a proclamação da República em Portugal (1910), a Primeira Guerra Mundial (19141918), a crise de 1929 e a Segunda Guerra Mundial (1939-1945), segundo Carlos Fontes (s.d.). Entre 1900 e 1950, o Brasil recebeu 903.186 migrantes legais portugueses, contudo, o autor considera que a quantidade real terá sido certamente muito superior. O perfil do migrante português da primeira metade do século XX, segundo Fontes (s.d.), era de origem majoritariamente agrária, oriundos das regiões centro-norte do país e das Regiões Autônomas dos Açores e da Madeira e com pouca alfabetização.

Fontes (s.d,) observa que o processo de adaptação desses migrantes no país e o apoio necessário na sua chegada, para a consequente inserção social, advinham da própria comunidade, ancorados nas redes de solidariedade entre os próprios migrantes, assim como num conjunto de instituições por eles criadas que facilitavam a sua integração social e política. Esta união foi possível por conta do espírito colaborativo e associativo dos migrantes. Algumas dessas associações fundadas pelos migrantes portugueses no início do século XX foram as bandas filarmônicas, criadas nos moldes das bandas filarmônicas em Portugal.

Apresentamos abaixo um quadro contendo as bandas filarmônicas portuguesas identificadas no Brasil através de pesquisa em periódicos. Este quadro, dividido por estados, apresenta o nome da Banda, a cidade onde foi fundada e, quando foi possível identificar, o ano ou período de sua fundação. 
Quadro 1. Bandas filarmônicas portuguesas no Brasil catalogadas por estado

\begin{tabular}{|c|c|c|c|}
\hline \multicolumn{4}{|c|}{ Estado do Rio de Janeiro } \\
\hline PAÍS & NOME DA BANDA & CIDADE & $\begin{array}{l}\text { ANO DE } \\
\text { FUNDAÇÃO }\end{array}$ \\
\hline Brasil & Centro Musical da Colônia Portuguesa & Rio de Janeiro & 1920 \\
\hline Brasil & $\begin{array}{l}\text { Nova Banda da Colônia Portuguesa (Banda } \\
\text { Portugal) }\end{array}$ & Rio de Janeiro & 1921 \\
\hline Brasil & Banda Lusitana & Rio de Janeiro & 1923 \\
\hline Brasil & Banda União Portuguesa & Rio de Janeiro & 1924 \\
\hline Brasil & Banda Lusitana de Niterói * & Niterói & \\
\hline Brasil & $\begin{array}{l}\text { Centro Musical Beneficente da Colônia } \\
\text { Portuguesa (Banda Portuguesa de Niterói) }\end{array}$ & Niterói & 1929 \\
\hline Brasil & Sociedade Musical Brasil-Portugal & Rio de Janeiro & 1955 \\
\hline Brasil & Banda Irmãos Pepino & Rio de Janeiro & 1958 \\
\hline Brasil & Banda Portuguesa da Guanabara ** & Rio de Janeiro & \\
\hline Brasil & Banda Luso-Brasileira de Niterói & Niterói & 1993 \\
\hline \multicolumn{4}{|c|}{ Estado de São Paulo } \\
\hline PAIS & NOME DA BANDA & CIDADE & $\begin{array}{l}\text { ANO DE } \\
\text { FUNDAÇÃO }\end{array}$ \\
\hline Brasil & Banda do Real Clube Ginástico Português & São Paulo & $\begin{array}{l}\text { Década de } \\
1880\end{array}$ \\
\hline Brasil & Sociedade Musical Luso-Brasileira *** & Santos & \\
\hline Brasil & Sociedade Musical Lusitana $* * *$ & Santos & \\
\hline Brasil & Banda Colonial Portuguesa $* * *$ & Santos & \\
\hline Brasil & Banda da Sociedade União Portuguesa & Santos & 1913 \\
\hline \multicolumn{4}{|c|}{ Estado do Amazonas } \\
\hline PAÍS & NOME DA BANDA & CIDADE & $\begin{array}{l}\text { ANO DE } \\
\text { FUNDAÇÃO }\end{array}$ \\
\hline Brasil & Banda do Luso Sporting Club & Manaus & $\begin{array}{l}\text { Década de } \\
1910\end{array}$ \\
\hline
\end{tabular}


* Com atividade documentada no Jornal do Commercio, de 04/04/1932 e 05/04/1932; no O Jornal, de 04/04/1932; no Jornal A Noite, de 03/01/1933 e; no Jornal Correio da Manhã, de 18/05/1933.

** Com atividade documentada no Jornal Diário de Notícias, de 11/08/1972, 13/08/1972, 30/08/1972 e 30/08/1975. Atividade também documentada no Jornal dos Sports de 13/01/1982.

*** Com atividade documentada na matéria "Bandas Musicais do Passado Santista”, publicada no Almanaque de Santos de 1971 (RODRIGUES, 1970, p. 84 -85).

A primeira banda portuguesa que conseguimos identificar, no Brasil, através da pesquisa em periódicos, foi a Banda do Real Clube Ginástico Português, fundada no Estado de São Paulo na década de 1880. A matéria extraída do jornal Correio Paulistano de 05 de maio de 1882, divulga a participação desta banda em um festival organizado em homenagem ao primeiro centenário de falecimento do Marquês de Pombal. A matéria cita que: "O Real Club Gymnsatico Potuguez, com sua banda em uniforme e toda a sua corporação, estará no Pateo da Academia onde reunidos aos distinctos acadêmicos e diversas comissões percorrerão as ruas da Cidade" (Correio Paulistano - 05 de maio de 1882, p. 4).

Com base no Quadro 1, observa-se, também, que, na década de 1910, foram fundadas a Banda da Sociedade União Portuguesa (1913), em Santos, no estado de São Paulo, e a Banda do Luso Sporting Club, na cidade de Manaus, estado do Amazonas. Sobre a participação da banda em um torneio de futebol realizado entre o Luso Sporting Club e o Rio Negro, a matéria informa que "Durante os encontros tocou a banda do Luso Sporting Club" (Jornal do Commercio - 31 de março de 1919).

No Álbum da Colônia Portuguesa no Brasil (1929) encontramos, também, referências a estas duas bandas como algumas das representantes da filarmonia portuguesa no Brasil. Elaborado para a Exposição Internacional de Sevilha e editado por Theóphilo Carinhas, o Álbum da Colônia Portuguesa no Brasil procura descrever, de forma quase épica, a trajetória da colônia portuguesa desde o final do século XIX, enfatizando o papel do empreendedorismo lusitano no processo de modernização da sociedade 
brasileira e enaltecendo os feitos da comunidade e dos migrantes portugueses nas mais diversas áreas como comércio, indústria, agropecuária, artes e beneficência, entre outras.

O Álbum da Colônia Portuguesa no Brasil (1929) faz, também, referência a duas bandas filarmônicas portuguesas no então estado da Guanabara, atual cidade do Rio de Janeiro - a Banda do Centro Musical da Colônia Portuguesa, fundada em 1920, e a Banda Lusitana, fundada em 1923 -, a partir de uma dissidência da Banda do Centro Musical da Colônia Portuguesa, conforme matéria publicada no Jornal O Brasil, de 26 de junho de 1923, na qual, em carta aberta à comunidade portuguesa, os músicos esclarecem o motivo da dissidência e anunciam:

Nós todos unidos depois da afronta que recebemos, viemos confiantes e cheios de vontade, embora as grandes dificuldades que atravessamos, organizar uma nova sociedade a quem demos o nome patriótico e cheio de fé "Banda Lusitana", a qual espera receber os conceitos e valores da colônia portuguêza e dos demais amigos que nos queiram considerar como até aqui achando-nos às suas estimadas ordens à Rua Vasco da Gama, n. 13, $1^{\circ}$ andar. (Jornal O Brasil - 26 de junho de 1923 - Coluna Vida Portuguesa - p. 6)

O Álbum da Colônia Portuguesa no Brasil, curiosamente, não faz referência à Banda Portugal, fundada em 1921 sob o nome de Sociedade Nova Banda da Colônia Portuguesa, também a partir de uma dissidência da Banda do Centro Musical da Colônia Portuguesa, e à Banda União Portuguesa, fundada em 1924, possivelmente porque era necessário pagar uma cota para a divulgação das instituições nesta publicação e estas bandas, à altura, não quiseram ou não puderam fazê-lo. 
Figura 4 - Banda do Centro Musical da Colônia Portuguesa

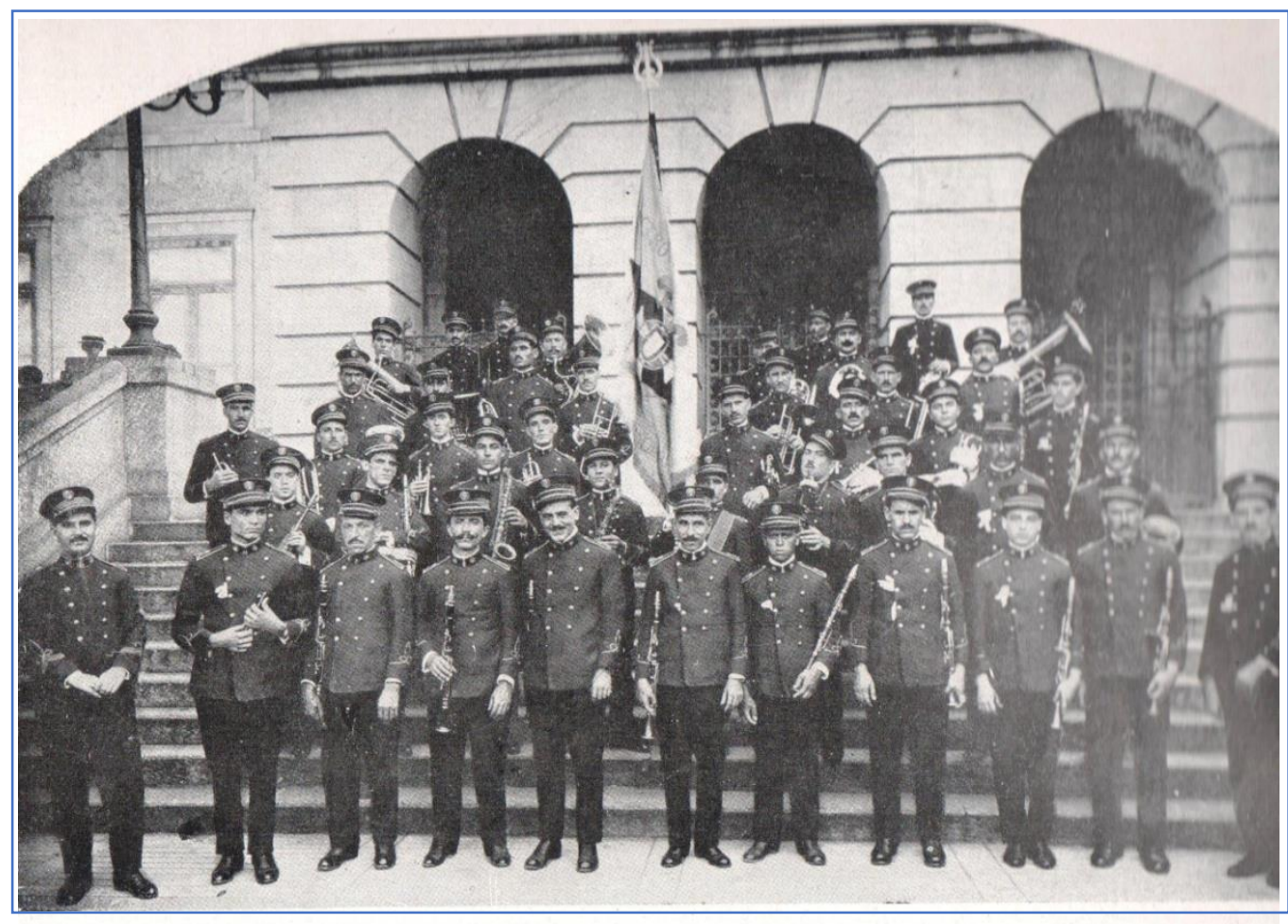

Banda do Centro Musical da Colónia Portuguesa

Fonte: Álbum da Colônia Portuguesa no Brasil (1929) - p. 122

A pesquisa em periódicos revelou que estes grupos cumpriam um papel cultural relevante na comunidade portuguesa da cidade do Rio de Janeiro no século XX, apresentando-se em teatros e ao ar livre, festas religiosas, festivais e atividades beneficentes.

Até meados da década de 1990, existiam, no estado do Rio de Janeiro, quatro bandas filarmônicas portuguesas: Banda Portugal (1921), Banda Lusitana (1923-1998), Banda Portuguesa de Niterói (1929-1991) e Banda Irmãos Pepino (1958). Atualmente só estão em atividade, no país, a Banda Portugal e a Banda Irmãos Pepino, ainda assim, de forma bastante precária se compararmos ao apogeu que vivenciaram até o final da década de 1980. Contudo, é relevante observar que foi no estado do Rio de Janeiro que as bandas filarmônicas portuguesas alcançaram maior longevidade no Brasil, certamente, pelo fato de ter sido a capital do país até 1960 e por conta da numerosa comunidade portuguesa migrante existente, até os dias atuais naquela cidade. 


\subsection{Bandas filarmônicas portuguesas nos Estados Unidos}

A história da diáspora portuguesa para os Estados Unidos se inicia, segundo Eduardo Ricou (2006), com a história de outra diáspora - a dos judeus portugueses. Em 1492, a Espanha já proclamara a expulsão dos judeus que não aceitaram a conversão do seu território, e em 1497, o Rei D. Manuel de Portugal expulsou, também, os “hereges" (mouros e judeus) de Portugal por conta de uma cláusula imposta por Isabel de Espanha para casar-se com ele. Ricou (2006) relata que, em 1752, um judeu convertido em cristãonovo, de nome Aaron Lopez, fugiu para os Estados Unidos e se radicou na cidade portuária de New Bedford, no atual estado do Massachusetts, região da Nova Inglaterra, onde iniciou suas atividades comerciais com a pesca da baleia para extração de óleo que era utilizado na fabricação de velas. Sua frota de veleiros cruzava o Oceano Atlântico para realizar as transações comerciais e fazia escala no Arquipélago dos Açores, em especial na Ilha do Faial, cuja baía era a mais apropriada para receber as pesadas embarcações. Havia, também, escalas em Cabo Verde nas quais as embarcações eram abastecidas, e açorianos e cabo-verdianos eram contratados como tripulantes. A este respeito, Onésimo de Almeida (2009) considera que a formação de uma colônia portuguesa propriamente dita, nos Estados Unidos, começou nos finais do século XVIII e foi aumentando no início do século XIX. Segundo o autor, os barcos baleeiros americanos tinham de fazer escala nos Açores por razões idênticas às que levaram os portugueses da época dos descobrimentos a eleger as ilhas como porto de escala, exemplo seguido pelos espanhóis, no circuito entre a Nova Espanha e o velho reino. De Boston, iam mantimentos, o correio e as mulheres dos capitães que se encontravam na Ilha do Faial, com os barcos vindos do Atlântico Sul e do Pacífico.

A caça à baleia, tanto na região da Nova Inglaterra como na Califórnia, foi o motor, segundo João Leal (2007), da migração açoriana, no século XIX, para essas regiões. O declínio da atividade da caça às baleias, no final do século XIX, não diminuiu, no entanto, o crescente fluxo migratório, e os migrantes dessas regiões transferiram-se, então, para novas atividades comerciais conforme relata o autor: 
No caso da Nova Inglaterra, a par de segmentos de imigrantes que passam então a dedicar-se à pesca e à agricultura, a maioria dos imigrantes irá empregar-se na indústria têxtil, particularmente nas cidades de New Bedford MA e Fall River MA, que se tornam então os dois mais importantes centros têxteis dos EUA. No caso da Califórnia, além de pequenas comunidades que se dedicaram à pesca, a maioria dos emigrantes transita para a agricultura ocupando-se em farms e na criação de gado leiteiro. (LEAL, 2007, p. 12)

Leal (2007) observa, ainda, que 90\% da migração portuguesa para os EUA foi composta por açorianos e divide os fluxos migratórios para os Estados Unidos em dois momentos. O primeiro momento, que vai do século XIX até a década de 1920, sofre uma interrupção por conta das leis anti-imigração impostas pelo governo americano. Aliada às leis anti-imigração, a crise de 1929 fez com que cerca de 20.000 açorianos retornassem ao arquipélago, segundo Leal (2007), que analisa os números da migração açoriana para os Estados Unidos, entre 1870 e 1930, e sua distribuição geográfica:

Este primeiro movimento migratório manteve-se até a grande depressão de 1929 e apresenta números expressivos. Se em 1870 o número de imigrantes açorianos nos EUA foi contabilizado em 9.000, em 1930 era já de cerca de 280.000 [...]. Destes, aproximadamente 35\% residiam na Califórnia e 40\% nos estados de Massachusetts e Rhode Island, na Nova Inglaterra. (LEAL, 2007, p. 12-13)

O segundo momento da migração açoriana para os Estados Unidos ocorreu após a erupção do vulcão dos Capelinhos, na Ilha do Faial, nos anos de 1957 e 1958, segundo Leal (2007). A publicação do Immigration Act, em 1965, reviu as limitações à migração impostas desde os anos 1920 e deu novo impulso à migração de açorianos nas décadas de 1960, 1970 e 1980 que procuraram se estabelecer nas mesmas regiões geográficas do primeiro grande fluxo migratório: Nova Inglaterra e Califórnia. A respeito deste novo momento da migração, Almeida (2009) atesta que, a partir de 1966, iniciou-se, então, um verdadeiro êxodo dos Açores. A cada país foi atribuída uma cota máxima para emissão de vistos e, a Portugal, coube a concessão máxima de 20.000 vistos por ano, número que, segundo o autor, nunca foi, nem de perto, atingido. Apenas a seguir ao 25 de Abril, entre 1976 e 1980, alguns anos conseguiram ultrapassar os 10.000 migrantes. 
Alguns fatores são atribuídos para a queda da migração portuguesa para os Estados Unidos, a partir da década de 1980: a entrada de Portugal na União Europeia (1986) e a consequente melhoria do nível de vida no país; as profundas alterações na economia americana, que praticamente extinguiu as empresas fabris que empregavam mão de obra não qualificada, transferindo-as para o Oriente; e a explosão da terceira revolução industrial com o advento das indústrias de informática e de biotecnologia, por exemplo, que exigiam mão de obra altamente qualificada. Almeida (2009) atesta que o número de vistos concedidos anualmente, a partir de então, desceu para menos de mil.

Apresentamos abaixo um quadro contendo as bandas filarmônicas portuguesas catalogadas nos Estados Unidos. Este quadro, dividido por estados, apresenta o nome da Banda, a cidade onde ela está sediada e, quando foi possível identificar, o ano de sua fundação.

Quadro 2. Bandas Filarmônicas Portuguesas nos Estados Unidos catalogadas por estado

\begin{tabular}{|c|c|c|c|}
\hline \multicolumn{4}{|c|}{ Estado de Massachusetts } \\
\hline PAÍs & NOME DA BANDA & CIDADE & $\begin{array}{l}\text { ANO DE } \\
\text { FUNDAÇÃO }\end{array}$ \\
\hline EUA & Banda Santo António de Fall River & Fall River, MA & 1904 \\
\hline EUA & Banda da Nossa Senhora da Luz & Fall River, MA & 1969 \\
\hline EUA & Filarmónica Santo António - Centro Cultural & Cambridge, MA & 1972 \\
\hline EUA & Banda Recreativa Portuguesa de Peabody & Peabody, MA & 1974 \\
\hline EUA & Sociedade Filarmónica de São João & Stoughton, MA & 1981 \\
\hline EUA & Banda de Nossa Senhora dos Anjos & New Bedford, MA & 1982 \\
\hline EUA & Banda Açoriana de Fall River & Fall River, MA & \\
\hline EUA & Banda Filarmónica Santa Cecília & Fall River, MA & \\
\hline EUA & $\begin{array}{l}\text { Banda Nossa Senhora da Conceição } \\
\text { Mosteirense }\end{array}$ & Fall River, MA & \\
\hline EUA & Banda do Senhor da Pedra de New Bedford & New Bedford, MA & \\
\hline EUA & Banda do Espírito Santo & Lowell, MA & \\
\hline
\end{tabular}




\begin{tabular}{|c|c|c|c|}
\hline \multicolumn{4}{|c|}{ Estado de Rhode Island } \\
\hline PAís & NOME DA BANDA & CIDADE & $\begin{array}{l}\text { ANO DE } \\
\text { FUNDAÇÃO }\end{array}$ \\
\hline EUA & Banda Independente Portuguesa & Bristol, RI & 1918 \\
\hline EUA & $\begin{array}{l}\text { Banda do Clube Juventude Lusitana (Lusitana } \\
\text { Band) }\end{array}$ & Cumberland, RI & 1926 \\
\hline EUA & Banda Filarmónica Santa Isabel & Bristol, RI & 1990 \\
\hline EUA & Banda Nova Aliança de Santo António & Pawtucket, RI & 1993 \\
\hline EUA & Banda Lira São Francisco Xavier & Providence, $\mathrm{RI}$ & 1993 \\
\hline EUA & $\begin{array}{l}\text { Banda Filarmónica de Nossa Senhora do } \\
\text { Rosário }\end{array}$ & Providence, $\mathrm{RI}$ & \\
\hline \multicolumn{4}{|c|}{ Estado de New Jersey } \\
\hline PAís & NOME DA BANDA & CIDADE & $\begin{array}{l}\text { ANO DE } \\
\text { FUNDAÇÃO }\end{array}$ \\
\hline EUA & $\begin{array}{l}\text { Banda Filarmónica da Igreja de Nossa Senhora } \\
\text { de Fátima }\end{array}$ & Newark, NJ & 1975 \\
\hline \multicolumn{4}{|c|}{ Estado da Califórnia } \\
\hline PAís & NOME DA BANDA & CIDADE & $\begin{array}{l}\text { ANO DE } \\
\text { FUNDAÇÃO }\end{array}$ \\
\hline EUA & Portuguese Band of San José & San José, CA & 1971 \\
\hline EUA & $\begin{array}{l}\text { Filarmónica do Artesia D.E.S. (Divino Espírito } \\
\text { Santo) }\end{array}$ & Artesia, CA & 1972 \\
\hline EUA & Sociedade Filarmónica Nova Aliança & San José, CA & 1973 \\
\hline EUA & Sociedade Filarmónica União Portuguesa & Santa Clara, CA & 1974 \\
\hline EUA & Filarmónica Nova Artista Açoriana & Tracy, CA & 1975 \\
\hline EUA & Filarmónica Recreio do Emigrante Português & Newark, CA & 1978 \\
\hline EUA & Sociedade Filarmónica União Popular & Santa Clara, CA & 1978 \\
\hline EUA & Filarmónica Artista Amadora & San Leandro, CA & 1980 \\
\hline EUA & Azores Band of Escalon & Escalon, CA & 1980 \\
\hline EUA & Filarmónica Portuguesa de Tulare & Tulare, CA & 1981 \\
\hline EUA & Sociedade Filarmónica Lira Açoriana & Livingston, $\mathrm{CA}$ & 1982 \\
\hline EUA & Filarmónica do Chino D.E.S. & Chino, CA & 1986 \\
\hline EUA & Lusitania Band of The North Bay & Novato, CA & 1996 \\
\hline EUA & Filarmónica União Portuguesa & San Diego, CA & 1998 \\
\hline
\end{tabular}


O quadro acima informa que a Banda Santo António, de Fall River, fundada em 1904, e a Banda Independente Portuguesa, em 1918, são anteriores à primeira banda filarmônica portuguesa fundada na cidade o Rio de Janeiro, em 1920. Podemos observar que a maioria das bandas catalogadas foram fundadas após 1970, o que nos permite concluir que estes grupos tiveram suas origens no fluxo migratório que ocorreu nas décadas de 1960, 1970 e 1980. Podemos constatar, também, a influência do aspecto religioso e da Igreja Católica, pois várias bandas possuem nomes de santos ou a sigla D.E.S. (Divino Espírito Santo) em seus nomes quando estão vinculadas às irmandades do Divino Espírito Santo. Para Evilásio Teixeira (2013), é possível falar-se em uma cultura lusoaçoriana, que se caracteriza pela forte devoção ao Espírito Santo, manifestada através das Irmandades do Divino Espírito Santo espalhadas pelos países para onde houve grande afluxo de açorianos. O povo luso-açoriano manifesta a sua fé e sua relação com o sagrado com o culto às bandeiras do Divino, da pomba do Espírito Santo e das festas do Divino.

A devoção ao Divino Espírito Santo é um dos traços mais marcantes da cultura açoriana, constituindo um culto que, para além de marcar o cotidiano do arquipélago, determina traços identitários que acompanham os açorianos para todos os lugares para onde migraram, aí incluídos a América do Norte e também o Brasil. Além de observarmos no quadro acima bandas com nomes de santos, vemos outras tantas com referências aos Açores, o que indica o grande fluxo de migrantes desta Região Autônoma para os Estados Unidos. Também é interessante ressaltar que muitas bandas, apesar de sediadas nos Estados Unidos, têm seus nomes em língua portuguesa o que nos possibilita inferir que o idioma funciona, também, como elemento de identidade e coesão do grupo (Halbwachs, 2003).

Apresentamos, abaixo, uma descrição encontrada na homepage da Azores Band of Escalon, situada no Estado da Califórnia, que nos permite compreender em que tipos de eventos e festividades a banda costuma se apresentar:

A Banda dos Açores de Escalon foi fundada em 1980 por imigrantes portugueses locais, com o desejo de manter as tradições musicais de sua terra natal. A Filarmônica se apresenta em festas locais, touradas, e em muitos outros eventos realizados pela comunidade portuguesa. A Banda dos Açores de Escalon é conhecida por suas performances enérgicas nas 
touradas realizadas no Vale de San Joaquin e é considerada uma das melhores bandas taurinas da Califórnia. (www.azoresbandofescalon.com - acesso realizado em: 15/11/2017. Tradução nossa)

John Philip Sousa foi um dos principais expoentes da música para instrumentos de sopros no mundo. Sousa, considerado o "Rei das Marchas", segundo Pinto (2010), era filho de um migrante açoriano casado com uma alemã e nasceu nos Estados Unidos. Foi autor de diversas marchas, canções e operetas e consagrou-se, também, como maestro, primeiramente regendo a Banda dos Fuzileiros Navais e, posteriormente, a sua própria banda, a Sousa's Band com a qual se apresentou para milhares de pessoas em diversas turnês pelos Estados Unidos e internacionais que incluíram viagens pela Europa, Austrália e África, no início do século XX. É autor da marcha "The Star and Stripes Forever", considerada a marcha oficial dos Estados Unidos.

\subsection{Bandas filarmônicas portuguesas no Canadá}

O Relatório da Viagem da Comissão de Política Geral ao Canadá produzido pela Assembleia Legislativa Regional da Região Autônoma dos Açores, em 2002, afirma que a migração portuguesa para o Canadá tem uma história recente. Somente a partir de 1953 , com a assinatura de acordos bilaterais entre os governos de Portugal e do Canadá, relativos à entrada de migrantes portugueses naquele país e, com a chegada do primeiro contingente oficial de 555 portugueses trazidos pelo navio Saturnia ao porto de Halifax, no dia 13 de maio de 1953, pode-se considerar o início de um movimento migratório português efetivo. No ano seguinte, esse número triplicou. Ainda segundo o relatório, o governo canadense promoveu a migração portuguesa nos anos 1950 e 1960 a fim de suprir as suas necessidades de mão de obra, destinadas ao setor agrícola e à construção de linhas-férreas. A maior parte desses migrantes era proveniente dos meios rurais, e entre 1953 e 1973, teriam entrado no Canadá 91.583 portugueses, sendo 61,2\% originários dos Açores.

Abaixo, apresentamos um quadro contendo as bandas filarmônicas portuguesas catalogadas no Canadá. Este quadro, da mesma forma que os quadros anteriores, referente às bandas Filarmônicas portuguesas no Brasil e nos Estados Unidos, está dividido por províncias, denominação adotada no Canadá e equivalente ao estado no 
Quadro 3. Bandas Filarmônicas Portuguesas no Canadá catalogadas por província

\begin{tabular}{|c|c|c|c|}
\hline \multicolumn{4}{|c|}{ Província de Alberta } \\
\hline PAÍs & NOME DA BANDA & \multirow{2}{*}{$\begin{array}{l}\text { CIDADE } \\
\text { Calgary }\end{array}$} & \multirow{2}{*}{$\begin{array}{l}\text { ANO DE FUNDAÇÃO } \\
1983\end{array}$} \\
\hline Canadá & $\begin{array}{l}\text { Associação Filarmónica Portuguesa de } \\
\text { Calgary }\end{array}$ & & \\
\hline Canadá & Filarmónica do Coração de Jesus & Calgary & \\
\hline \multicolumn{4}{|c|}{ Província de Quebec } \\
\hline PAÍS & NOME DA BANDA & CIDADE & ANO DE FUNDAÇÃO \\
\hline Canadá & Filarmónica Portuguesa de Montreal & Montreal & 1972 \\
\hline Canadá & $\begin{array}{l}\text { Filarmónica do Divino Espírito Santo de } \\
\text { Laval }\end{array}$ & Montreal & 1978 \\
\hline Canadá & Banda de Nossa Sra. Dos Milagres & Montreal & \\
\hline Canadá & Filarmónica Nossa Sra. de Fátima & Gatineau & \\
\hline \multicolumn{4}{|c|}{ Província de Ontario } \\
\hline PAís & NOME DA BANDA & CIDADE & ANO DE FUNDAÇÃO \\
\hline Canadá & Banda do Senhor Santo Cristo & Toronto & 1966 \\
\hline Canadá & Filarmónica Lira Bom Jesus & Oakville & 1968 \\
\hline Canadá & $\begin{array}{l}\text { Banda Lira do Espírito Santo em } \\
\text { Cambridge }\end{array}$ & Cambridge & 1970 \\
\hline Canadá & Banda do Sagrado Coração de Jesus & Toronto & 1974 \\
\hline Canadá & Banda Lira Portuguesa de Bramptom & Bramptom & 1976 \\
\hline Canadá & Banda Lira de Fátima em Cambridge & Cambridge & \\
\hline Canadá & Portuguese Community Band of Hamilton & Hamilton & \\
\hline Canadá & The Music Societ of Saint Helen's & Toronto & \\
\hline \multicolumn{4}{|c|}{ Província de British Columbia } \\
\hline PAÍs & NOME DA BANDA & CIDADE & ANO DE FUNDAÇÃO \\
\hline Canadá & $\begin{array}{l}\text { Banda Filarmónica Portuguesa de } \\
\text { Vancouver }\end{array}$ & Vancouver & \\
\hline Canadá & $\begin{array}{l}\text { Banda Filarmónica Sociedade Musical } \\
\text { Portuguesa }\end{array}$ & Vancouver & \\
\hline Canadá & Lira Portuguesa de Victoria & Victoria & \\
\hline
\end{tabular}


De acordo com o quadro acima, a banda filarmônica portuguesa mais antiga que se conseguiu catalogar, no Canadá, é a Banda do Senhor Santo Cristo, fundada em 1966. A maioria das bandas catalogadas foi fundada na década de 1970, ou seja, decorrentes do fluxo migratório português e, sobretudo, açoriano, iniciado em 1953 e, cujo auge foi atingido nos anos 1960. Assim como nos Estados Unidos, há várias bandas com nomes de santos, mais uma vez reiterando a forte influência do aspecto religioso e da Igreja Católica na formação e atuação das bandas filarmônicas portuguesas, assim como no país de origem. Também, como no caso americano, muitas das bandas mantêm seus nomes em língua portuguesa reafirmando, por meio da língua portuguesa, seus laços identitários com a terra natal.

Figura 5 - Associação Filarmónica Portuguesa de Calgary - Calgary - Alberta - Canadá

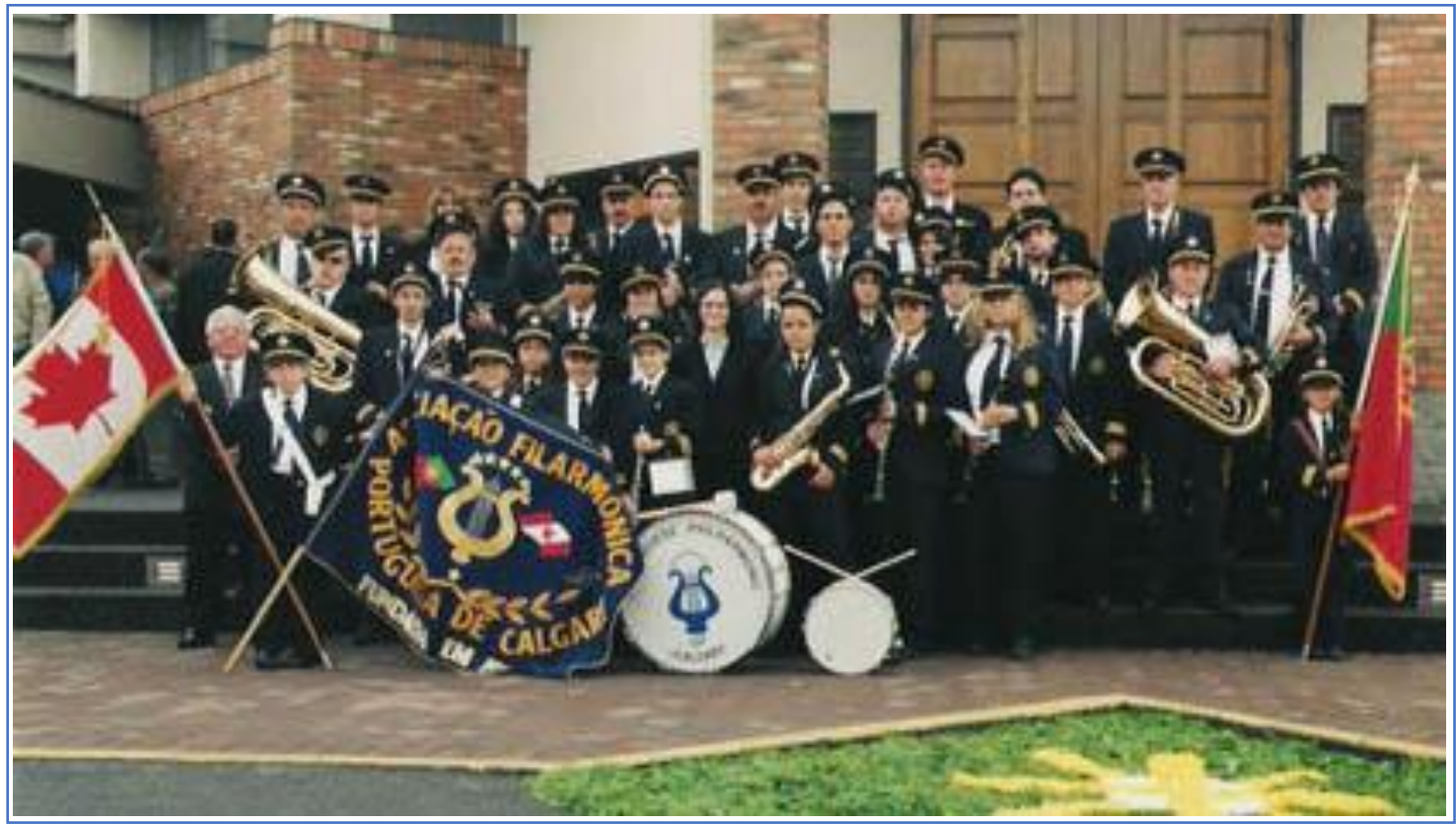

Fonte: www.bandasfilarmonicas.com. Acesso em 05/03/2016.

Na foto acima, da Associação Filarmónica Portuguesa de Calgary, podemos observar, à esquerda, a bandeira da banda com uma lira ao centro, simbolizando a música, circundada pelas bandeiras de Portugal e do Canadá. O uniforme da banda reflete a influência das bandas militares como observamos anteriormente nas bandas filarmônicas em Portugal. 
A foto abaixo mostra a "linha de frente" da Banda do Senhor Santo Cristo, banda filarmônica portuguesa mais antiga do Canadá, na procissão do Senhor Santo Cristo dos Milagres. Podemos observar o estandarte da banda, em primeiro plano, carregado por duas crianças uniformizadas com os mesmos trajes dos músicos. No estandarte constam o nome da banda, o ano de sua fundação e a localidade à qual ela pertence, a cidade de Toronto. Também podemos observar, ao centro do estandarte, uma lira, representando a música, e, no seu interior, a imagem do Senhor Santo Cristo. Logo atrás, da esquerda para a direita, podemos visualizar as bandeiras do Canadá, da Província de Ontário, da qual Toronto é a capital, da Região Autônoma dos Açores e, por fim, a bandeira de Portugal. Logo a seguir, atrás das bandeiras, vêm os diretores da banda, o maestro e a banda de música.

Figura 6 - Banda do Senhor Santo Cristo - Toronto - Ontário - Canadá

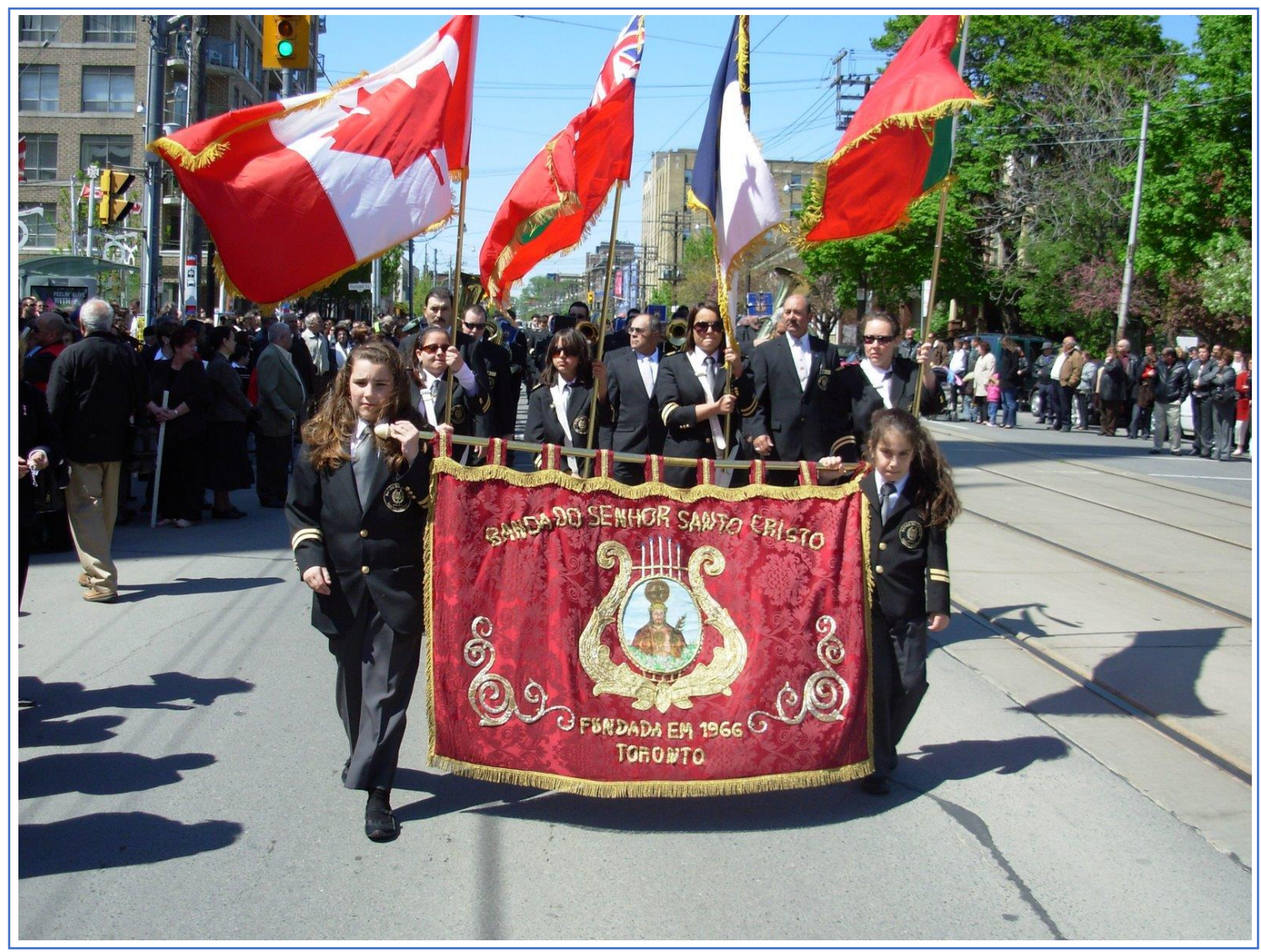

Fonte: <http://omilhafre-noticias.blogspot.com.br/2009_05_01_archive.html> (acesso realizado em 01/03/2016). 


\subsection{Banda Recreativa Madeirense de Venezuela}

A Venezuela, conforme atesta Nancy Gomes (2009), é o segundo país da América Latina em número de migrantes portugueses com cerca de 500.000, atrás apenas do Brasil. A autora afirma que $75 \%$ dos migrantes portugueses que entraram na Venezuela são oriundos da Região Autônoma da Madeira, e há, também, registros de contingentes de migrantes oriundos dos Distritos do Porto, Coimbra e Aveiro.

A presença portuguesa na Venezuela, conforme relata Gomes (2009), ocorre desde a época das grandes navegações, pois há registros históricos que atestam que vários tripulantes portugueses viajaram na expedição de Cristóvão Colombo (1492). A expedição de Américo Vespúcio que explorou a costa da Venezuela, em 1499, adentrou, em agosto daquele ano, o Lago de Maracaibo, onde encontrou nativos cujas casas eram palafitas construções sobre estacas fixas de madeira. O navegador italiano achou aquelas construções semelhantes às da cidade de Veneza e, por isso, deu o nome à região de “Pequena Veneza”, ou seja, Venezuela.

Durante o período da colonização do território venezuelano, destaca-se, segundo Gomes (2009), o nome de João Fernandes de Leão e Pacheco, português, nascido em Portimão, região do Algarve, e fundador, em 1593, da cidade de Guanare, capital da Portuguesa, um dos 23 estados que compõem a Venezuela, e onde seu corpo se encontra sepultado. A autora afirma que, apesar da presença dos portugueses ser efetiva no século XVI, alguns historiadores afirmam que a primeira comunidade de portugueses se fixou na região só no início do século XVII.

Gomes (2009) afirma que as primeiras décadas do século XIX foram marcadas pelas guerras de independência na América Espanhola e atesta que alguns portugueses lutaram ao lado de Simón Bolivar na libertação da Venezuela. Após um período marcado por disputas políticas internas, Antonio Gusmán Blanco assumiu o poder, em 1870, e promoveu a migração europeia, facilitando, sobretudo, a entrada de migrantes oriundos das Ilhas Canárias. Com esses migrantes, entraram no país alguns portugueses.

A comercialização do primeiro poço de petróleo da Venezuela, em 1914, e a industrialização que se seguiu estimularam, no início do século $X X$, segundo Gomes 
(2009), a chegada de mais uma leva de migrantes europeus para o país, sobretudo de espanhóis, italianos e portugueses. Também a política de imigração do General Eleazar López Contreras, presidente entre 1936 e 1941, prevista no "Plano Global de Modernização Econômica", estimulou a entrada de trabalhadores estrangeiros, sobretudo da Europa, com o objetivo de suprir a necessidade de mão de obra nos setores agrícola e da construção civil e, segundo Gomes:

[...] é entre 1947 e 1952 que podemos falar de um verdadeiro boom de imigrantes. Há registro de que durante este período entraram na Venezuela perto de 800 mil imigrantes. Duas razões são apontadas: as difíceis condições de vida na Europa do pós-guerra e a política, uma vez mais favorável à imigração europeia, do novo Governo do general Marcos Pérez Jimenes, que governou o país entre 1952 e 1958. (GOMES, 2009, p. 84)

É importante ressaltar que muitos dos portugueses que se refugiaram na Venezuela, especialmente entre 1940 e 1960, o fizeram por motivos políticos, fugindo do regime ditatorial de António Salazar, em Portugal.

O movimento migratório para a Venezuela começa a diminuir a partir de 1958, mas toma novo fôlego a partir de 1973, movido pelo boom petrolífero, conforme observa Gomes (2009). A grande maioria dos migrantes desta época é de origem latinoamericana, mas junto migram, também, muitos portugueses motivados pela crise internacional do petróleo, além do aumento do desemprego e da desvalorização da moeda no pós Revolução dos Cravos (1974).

A década de 1980 foi um período de dificuldade econômica e conturbação política na América Latina e, diante deste cenário, a migração para a Venezuela estagna mais uma vez. As condições sociais internas se alteram e, com isso, muitos portugueses retornam à sua terra natal. Nos dias de hoje, registra-se um fluxo inverso de migrantes portugueses da Venezuela para Portugal, por questões relacionadas à insegurança e à instabilidade política naquele país.

Os migrantes portugueses na Venezuela, também conhecidos como lusovenezuelanos, dedicaram-se, inicialmente, à agricultura, mas depois de 1948, a grande 
maioria se dedicou ao comércio, sobretudo de alimentos. No país, conforme atesta Gomes (2009), os portugueses eram proprietários de, aproximadamente, oitenta por cento do total de padarias e sessenta por cento do total de mercearias.

Como é possível observar em diversas partes do mundo para onde há migração portuguesa, existem, na Venezuela, diversas associações recreativas que funcionam como polos de ligação social e também econômica atuando, inclusive, na criação de lobbys a fim de defender os interesses comerciais da comunidade luso-venezuelana como podemos observar na citação de Gomes, a seguir:

O Centro Português de Caracas - considerado o maior centro português da Venezuela e do mundo - chega a ser frequentado nos dias mais festivos, por cerca de 10 mil pessoas. Estes centros funcionam também como pólos de ligação e criação de lóbis, em especial os de cariz económico. Sendo locais por excelência de óptimo convívio e frequentemente visitados pela «fina-flor» da política venezuelana, a comunidade (com significativo peso económico) transforma-se num verdadeiro grupo de pressão na hora de definir políticas que mexem com os seus interesses. (GOMES, 2009, p. 87)

A banda não possui website, e as poucas informações que conseguimos foram obtidas através da página que o grupo mantém na rede social Facebook (https://www.facebook.com/BandaRecreativaMadeirenseDeVenezuela/), através da qual conseguimos contato com o administrador da página da banda que nos informou que o grupo mantém as suas atividades apesar do momento de instabilidade política e financeira que o país atravessa, além de uma matéria do Jornal Correio de Venezuela.

A Banda Recreativa Madeirense de Venezuela, conforme consta na matéria do Jornal Correio de Venezuela, datada de 02 de abril de 2015, teve sua criação não por motivações religiosas ou por influência da Igreja Católica, como as bandas filarmônicas em Portugal, e sim por conta de um time de futebol fundado por portugueses, em Caracas, em 1959, chamado Club Sport Marítimo de Venezuela, ou simplesmente "Marítimo", uma clara alusão ao Club Sport Marítimo, time de futebol da Ilha da Madeira e maior clube daquela Região Autônoma. Os irmãos Martinho e Manuel Pestana tocavam seus instrumentos nas arquibancadas dos estádios, durante os jogos do Marítimo, e 
atraíram a atenção de outros espectadores e torcedores que aderiram àquela iniciativa. $\mathrm{A}$ banda se apresentou, pela primeira vez, como grupo musical constituído, em 1986, na Plaza Venezuela, nas celebrações do aniversário do clube fundado pelos madeirenses. 0 clube de futebol acabou em 1995, mas os músicos decidiram seguir com a banda dandoIhe o nome atual.

Na página da banda na rede social Facebook, o grupo divulga suas atividades oferecendo entretenimento para festas ao estilo madeirense nas quais se pode experimentar, com sua música, a cultura portuguesa. Segue a sua descrição:

Banda instrumental com excelente repertório. A maioria de seus membros é da comunidade portuguesa e continuam cultivando a cultura portuguesa, que serve à nossa Virgem de Fátima em suas festas e também em qualquer tipo de eventos particulares. A única e melhor Banda Portuguesa na Venezuela, especificamente, em Caracas. (Disponível em: <www.facebook.com/BandaRecreativaMadeirenseDeVenezuela/info/?tab $=$ page_info $>$. Acesso em: 17 de agosto de 2017. Tradução nossa.)

Embora a banda não tenha sido criada sob a influência religiosa da Igreja Católica, observamos, na descrição acima, que o grupo faz referência a Nossa Senhora de Fátima e suas festas. A Venezuela é um país majoritariamente católico e, segundo Gomes (2009), a fé em Nossa Senhora de Fátima contagia há muito tempo o povo venezuelano, o que se torna evidente se considerarmos as inúmeras procissões que se realizam no dia 13 de maio, data atribuída como da primeira aparição de Nossa Senhora de Fátima, por todo o país. Também na descrição, podemos constatar que o grupo se identifica como "A única e melhor Banda Portuguesa na Venezuela", fato curioso se considerarmos o número de migrantes portugueses naquele país.

\section{Considerações Finais}

Constatamos que as bandas filarmônicas são das expressões musicais mais significativas da cultura popular portuguesa e a constituição de grupos performativos em contextos migrantes evoca memórias e lembranças da terra natal. 
A revisão de literatura sobre a diáspora portuguesa revelou que estes trânsitos foram marcados, no século XX, pela criação de bandas filarmônicas portuguesas e, neste artigo, pudemos observar a correlação entre os diferentes fluxos migratórios da migração portuguesa e a criação e manutenção destas bandas nos diferentes países de acolhimento.

A relação entre religião, música, migração e memória forma um mosaico que amalgama a configuração identitária dos migrantes portugueses, fornecendo-lhes elos de pertencimento simbólico à terra distante. A recriação/reiteração de práticas - as bandas filarmônicas - que reiteram simbolicamente um modus vivendi deixado para trás, promove um laço afetivo de pertencimento, de coesão. Neste sentido, a música é tomada como um dos quadros sociais da memória (Halbwachs, 1994) do migrante português, já que alicerça o jogo do lembrar e esquecer presente em toda operação de memória.

Observamos que o elemento diferenciador das bandas filarmônicas portuguesas com relação às suas congêneres reside no repertório que somente elas executam e estes grupos constituem verdadeiros lugares de memória (Nora, 1993).

No Brasil existem, atualmente, apenas duas bandas filarmônicas portuguesas em atividade, ainda assim, atuando de forma bastante precária se compararmos ao apogeu que vivenciaram até o final da década de 1980. Pudemos observar que muitas bandas foram criadas e encerraram suas atividades nos diversos estados da federação, situação que parece divergir das bandas portuguesas nos Estados Unidos e Canadá, por exemplo. A diminuição da colônia portuguesa no Brasil por conta do envelhecimento da comunidade migrante e da drástica diminuição da migração de Portugal para cá são certamente fatores que contribuíram para a situação atual das bandas portuguesas no Brasil, bem como a própria situação econômica do país e um histórico de não apoio a estes grupos musicais pelos poderes governamentais sejam eles, bandas portuguesas ou não. Para, além disto, países como Estados Unidos e Canadá têm, ainda, um considerável número de migrantes portugueses que tocam e participam das bandas e, conforme pude constatar através de contatos com músicos e maestros das bandas filarmônicas portuguesas nesses países, muitos migrantes de primeira e segunda gerações têm dado continuidade às bandas portuguesas, atuando como músicos, maestros e diretores, 
situação que, na vivência de 30 anos do autor nas bandas filarmônicas portuguesas da cidade do Rio de Janeiro, infelizmente, não observamos, o que acreditamos colaborar para a diferença destes grupos musicais com relação às congêneres no Brasil.

A pesquisa em periódicos locais nos tem permitido identificar a existência de diversas bandas filarmônicas portuguesas da cidade do Rio de Janeiro, contudo, conforme observamos no final da seção 3.1 deste artigo, é possível que o número de bandas portuguesas nessa cidade tenha sido ainda maior do que identificamos até o momento, pois, por exemplo, o Álbum da Colônia Portuguesa no Brasil (1929) só faz referência à existência de duas bandas portuguesas da cidade do Rio de Janeiro (então Distrito Federal), quando a pesquisa nos evidenciou que, no ano em que foi publicado, existiam, pelo menos, mais duas bandas portuguesas em atividade - a Banda Portugal (1921) e a Banda União Portuguesa (1924). A continuidade da pesquisa poderá revelar essa e outras informações a propósito destes grupos musicais da cidade do Rio de Janeiro.

\section{Referencias}

ALMEIDA, Onésimo Teotônio de. Comunidades portuguesas dos EUA: identidade, assimilação, aculturação. In: MATOS, Artur Teodoro de e LAGES, Mário, (Orgs.), Portugal. Percursos de Interculturalidade: Desafios à identidade. Lisboa: Alto Comissariado para a Imigração e Diálogo Intercultural, 2009, p. 339-422.

BAILY, John e COLLYER, Michael. Introduction: Music and Migration, Journal of Ethnical and Migration Studies. Vol. 32, No. 2, March 2006, p. 167- 182.

BRUCHER, Katherine M. A Banda da Terra: Bandas Filarmônicas and the Performance of Place in Portugal. Tese de Doutorado - University of Michigan, 2005.

\section{CABRAL, G. e MENESES, C.. Relatório da Viagem da Comissão de Política Geral ao}

Canadá. Assembleia Legislativa dos Açores. Região Autônoma dos Açores - Portugal, 2002. 
CARINHAS, Teóphilo. Álbum da Colônia Portuguesa no Brasil. Rio de Janeiro: Ed. Theóphilo Carinhas, 1929.

CHRISTELLO, J. Chris. Chronicaçores: Uma Circum-Navegação. De Timor à Austrália, Brasil, Bragança até aos Açores. Volume 3. Açores: VerAçor, 2010.

CÔRTE-REAL, Maria de São José. Revendo cidadania: migração e fado no jogo de identidades nos Estados Unidos. In: Revista Migrações, n. 7, outubro de 2010, p.73-97

FONTES, Carlos. (S.d.). Memórias da Emigração Portuguesa em França. Disponível em: <http://www.filorbis.pt/migrantes/page6franca.html>. Acesso em: 10 mar. 2016.

FREITAS, Pedro de. História da Música Popular em Portugal. Lisboa: Custódio Cardoso Pereira \& Ca, 1946.

GOMES, Nancy. Os Portugueses na Venezuela. In: Relações Internacionais, v.24. Lisboa Portugal, 2009, p. 183-192.

GRANJO, André. The Wind Band Movement in Portugal: Praxis and Constrains.

Dissertação de Mestrado - Zuid-Nederlands e Hogeschool vor Muziek, 2005.

HALBWACHS, Maurice. A Memória Coletiva. São Paulo: Centauro, 2003.

HALBWACHS, Maurice. Les Cadres Sociaux de la Mémoire. Paris: Albin Michel, 1994.

HOBSBAWM, Eric. A Era dos Impérios, 1875-1914. São Paulo: Paz e Terra, 2016.

HOLANDA, Sérgio Buarque de. Raízes do Brasil. São Paulo: Companhia das Letras, 1997.

LEAL, João. Açores, EUA, Brasil: Imigração e Etnicidade. Açores: Nova Gráfica Ltda., 2007.

NOGUEIRA, Ana Maria de Moura. Como Nossos Pais - Uma História da Memória da Imigração Portuguesa em Niterói (1900-1950). Dissertação de Mestrado - Universidade Federal Fluminense, 1998.

NOGUEIRA, Tristão. Modelos Predominantes de Espetáculos. In: Entre Bandas, v.2. Corroios, Portugal, 2010, p. 28-33.

NORA, Pierre. Entre memória e história: a problemática dos lugares. Em: Projeto História, v. 10, 1993, p. 7-28. 
PINTO, Jorge Costa. Coreto - Textos \#1 a \#100 do programa Coreto emitido pela RTPAntena 2. 08.01.06 a 23.03.08. Lisboa: Jorsom Publicações, 2010.

PIRES, Rui Pena (Coord.). Portugal: Atlas das Migrações Internacionais. Lisboa: Tinta da China, 2010.

RICOU, Eduardo (2006). Ei-los Que Partem - História da Imigração Portuguesa. Autor: Jacinto Godinho, Consultor Científico - Jorge Macaísta Malheiros, Pesquisa e documentação - Luísa Vaz. Portugal. RTP, 2006.

RODRIGUES, Olao. Almanaque de Santos. São Paulo: W. Roth \& Cia. Ltda., 1970, p. 84-85.

SOUSA, Pedro Alexandre Marcelino Marquês de. A Instituição Militar na História e Cultura Luso-Brasileira no Séc XIX - A História da Música Militar. Dissertação de Mestrado - Universidade de Lisboa, 2006.

TEIXEIRA, Evilásio Francisco Borges. A devoção do Espírito Santo na cultura lusoaçoriana. In: Navegações v. 6, n. 2, jul./dez. 2013. Pontifícia Universidade Católica do Rio Grande do Sul - Porto Alegre - Rio Grande do Sul - Brasil, 2013, p. 237-243.

TURINO, Thomas. Music as Social Life: the politics of participation. Chicago: The Universityof Chicago Press, 2008, p. 93-121. 